\title{
Study on the Relationship Between the Industrial Structure of Beijing-Tianjin-Hebe and the Energy Conservation and Emissions
}

\section{Reduction}

\author{
Wei Chen ${ }^{1, \mathrm{a}}$ and Jiao $\mathrm{Ma}^{2, \mathrm{~b}}$ \\ ${ }^{1}$ College of Economics and Management, Hebei University of Science and Technology, \\ Shijiazhuang, China, 050018 \\ ${ }^{2}$ College of Economics and Management, Hebei University of Science and Technology, \\ Shijiazhuang, China, 050018 \\ a chenwei0123@126.com, ${ }^{\mathrm{b}}$ maxiaojiaoz@126.com
}

Keywords: Industrial structure; Energy consumption; Carbon emissions; Grey correlation.

\begin{abstract}
As the core of the Bohai economic circle, the Beijing-Tianjin-Hebe region's economic development occupies an important position, but the industrial structure condition of Beijing-Tianjin-Hebe region is not optimistic. Based on the statistical data from 2005 to 2012, this article analyzes the Beijing-Tianjin-Hebe industrial energy consumption and carbon emissions intensity. The results found that with the growth of the heavily industrialized industrial structure of Beijing-Tianjin-Hebe, the energy consumption grow straightly, and it has increased by $52 \%$ in eight years. And the energy consumption per ten thousand Yuan has fallen from 1.00 tce to 0.56 tce, reflecting the progress of the consciousness of energy conservation and the technology of energy conservation. And industrial industries output value and energy consumption intensity of carbon emissions intensity are important influence factors, their basic correlation coefficient with carbon intensity are more than 0.6 .In addition, the influence of industrial sectors for carbon has a larger difference. The study provides scientific basis to achieve energy conservation and emissions reduction goal by structural adjustment.
\end{abstract}

\section{Introduction}

Since the "eleventh five year plan", Beijing-Tianjin-Hebe has carried on the industrial structure adjustment, upgraded the light industry and other traditional industries, cultivated heavy industry such as equipment manufacturing industry, petroleum chemical industry, and thermal power, and speeded up the development of electronic information, new energy, biological medicine and other high and new technology industry, promoted industry gathered themselves together, and eliminate backward production capacity, and significant progress was made in industrial structural adjustment.But its condition and industrial structure is not optimistic. The second industry account for a high proportion in the three industries, and heavy and light industry scale up to 8 to 2 .Heavy industrial structure will lead that resource, energy consumption is large, and the ecological environment worse and worse. There exist great correlation between industrial structure and resources and environment. Different industry will consume different amounts of energy, and 
produce different amounts of pollutants.Therefore, the analysis of the relationship between industrial structure and energy consumption and environmental pollution is of great significance.

\section{Analysis of the energy supply and demand and the industrial structure situation of Beijing-Tianjin-Hebe}

From Fig. 1, you can see that the energy supply and demand gap are 107.6852 million tons of standard coal in 2000 year, however, with the development of economy and the improvement of people's living standards, the energy supply and demand gap of beijing-tianjin-hebei is bigger and bigger, and it reached 303.3455 million tons of standard coal by 2012, which is 2.82 times of that of 2000. We also see the energy supply curve is flat, suggest that energy supply has been steady growth. Although the total amount has increased, but the growth is not large. While the total energy consumption presents a relatively steep growth trend, leading the energy supply and demand of beijing-tianjin-hebei is still unstable, and the supply and demand gap increases gradually, and its external dependence degree reached $66.47 \%$ by 2012 .

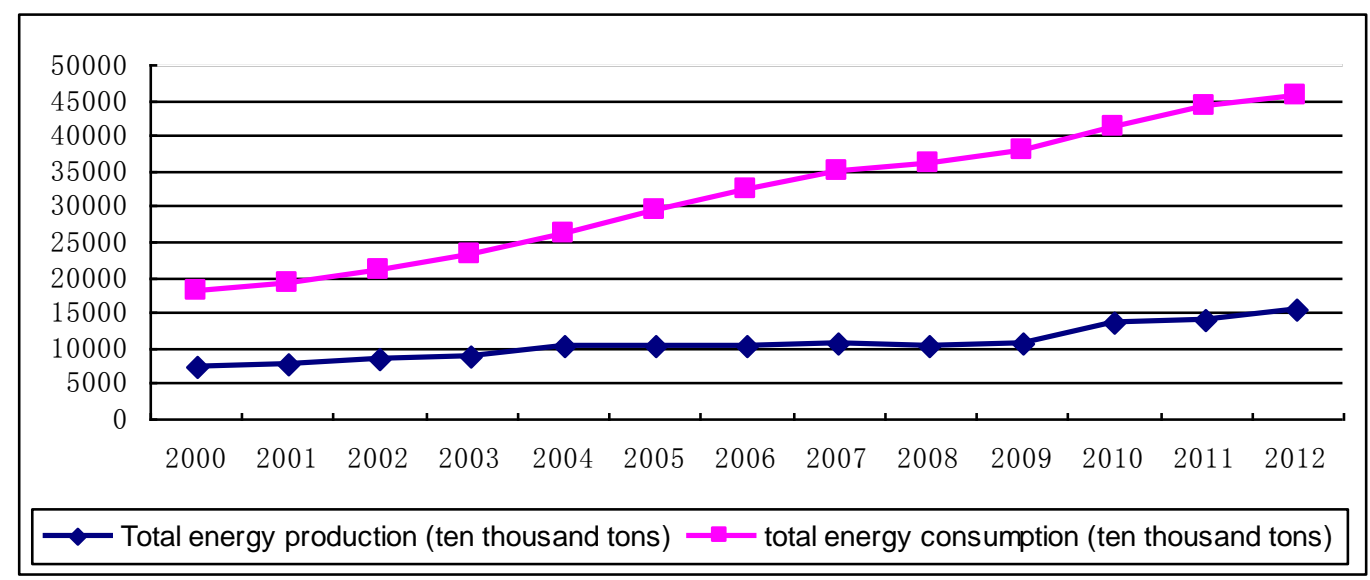

Data sources: 2006-2013《Hebe economy yearbook》,《 Beijing statistical yearbook 》,《Tianjin statistical yearbook》

Fig. 1 The total energy supply and demand of beijing-tianjin-hebe

Further analysis of the energy consumption of three industry structure of beijing-tianjin-hebei, which are shown in table 1 , shows that the proportion of energy consumption of each industry are relatively stable state. During the period of "11th five-year plan", the first industry has remained at about $2.6 \%$, and decreasd a little in the nearly past two years. Its energy consumption accounts for a small proportion. Industrial energy consumption proportion of the second industry has remained at about $79 \%$, and construction industry accounts for only $1.7 \%$ of the total. The third industry has accounted for about $16.6 \%$ of the total energy consumption.As high energy consumption industry, the second industry should reduce its proportion, and improve the proportion of tertiary industry, then it could reduce the energy consumption, and achieve the goal of low carbon economy.

Table 1 The proportion of each industry energy consumption of beijing-tianjin-hebei

\begin{tabular}{c|c|c|c|c}
\hline \multirow{2}{*}{ year } & \multirow{2}{*}{ primary industry } & \multicolumn{2}{|c|}{ secondary industry } & \multirow{2}{*}{ tertiary industry } \\
\cline { 3 - 5 } & & manufacture & construction industry & \\
\hline 2005 & $2.68 \%$ & $80.65 \%$ & $1.38 \%$ & $15.29 \%$ \\
\hline 2006 & $2.70 \%$ & $79.74 \%$ & $1.42 \%$ & $16.14 \%$ \\
\hline 2007 & $2.59 \%$ & $79.55 \%$ & $1.41 \%$ & $16.45 \%$ \\
\hline 2008 & $2.59 \%$ & $78.67 \%$ & $1.66 \%$ & $17.08 \%$ \\
\hline 2009 & $2.61 \%$ & $78.18 \%$ & $1.83 \%$ & $17.38 \%$ \\
\hline 2010 & $2.50 \%$ & $78.63 \%$ & $1.92 \%$ & $16.96 \%$ \\
\hline 2012 & $2.32 \%$ & $79.34 \%$ & $1.91 \%$ & $16.42 \%$ \\
\hline
\end{tabular}


Data sources: 2006-2013《Hebe economy yearbook》,《 Beijing statistical yearbook 》,《Tianjin statistical yearbook》

According to the related statistical data of beijing-tianjin-hebei industries from 2005 to 2012, the industry which accounts for a high proportion of beijing-tianjin-hebei gross industrial output value clearly focused on heavy industry. Black metal smelting and rolling processing industry which is the leading industry in beijing-tianjin-hebei is much higher than the proportion of other industries. Secondly are electricity and heat production and supply industry, transportation equipment manufacturing, communications equipment and computer and other electronic equipment manufacturing, etc.And smaller proportion of gross industrial output value of industry concentrated in light industry, such as, chemical fiber industry, water production and supply industry, etc.

\section{The energy consumption of beijing-tianjin-hebei industry and analysis of carbon emissions characteristics}

The measure of carbon emissions of beijing-tianjin-hebei industry. Carbon dioxide is the main gas emissions from energy consumption, so this article only considered the primary energy consumption carbon emissions.At present, the international method on estimating carbon emissions are mainly the measured method, material balance algorithm, and carbon emissions coefficient method. This paper will use carbon emissions coefficient method, and the consumption of coal, oil, gas, water and electricity, will respectively multiplicated their carbon emissions coefficient, including the hydropower coefficient of carbon emissions will be zero, computation formula such as (1) :

$$
Q_{t}=E_{t 1} \xi_{1}+E_{t 2} \xi_{2}+E_{t 3} \xi_{3}
$$

$Q_{t}$ stands for the carbon emissions of the year of $\mathrm{T}$, and $E_{t}$ stands for the consumption of coal of the year of T, $E_{t 2}$ stands for the consumption of oil of the year of T, $E_{t 3}$ stands for The consumption of natural gas of the year of $\mathrm{T}, \xi_{1} \xi_{2}, \xi_{3}$ are respectively the emission coefficient of coal, oil, natural gas carbon. The unit is tons of carbon/tons, but the unit of the energy consumption in the statistical yearbook is ten thousand tons of standard coal, so they need to convert into physical quantity. This paper will use the convert released by the national development and reform commission, which is 1 tons of standard coal $=1.4$ tons of coal $=0.7$ tons of oil $=0.5883$ tons of gas. Using the average of all kinds of carbon emission coefficient as the coefficient, such as in table 2 .

Table 2 carbon emissions coefficient table (units: tons carbon/tons)

\begin{tabular}{c|c|c|c|c}
\hline & Coal & Oil & Natural gas & $\begin{array}{c}\text { Water and } \\
\text { electricity }\end{array}$ \\
\hline $\begin{array}{c}\text { The U.S. department of energy } \\
\text { (DOE/EIA) }\end{array}$ & 0.7020 & 0.4780 & 0.3890 & 0 \\
\hline $\begin{array}{c}\text { Japan's energy economics research } \\
\text { institute }\end{array}$ & 0.7560 & 0.5860 & 0.4490 & 0 \\
\hline $\begin{array}{c}\text { The energy institute of national } \\
\text { development and reform commission }\end{array}$ & 0.7476 & 0.5825 & 0.4435 & 0 \\
\hline $\begin{array}{c}\text { National science and technology } \\
\text { commission project of climate change }\end{array}$ & 0.7260 & 0.5830 & 0.4090 & 0 \\
\hline Average & 0.7329 & 0.5574 & 0.4226 & 0 \\
\hline
\end{tabular}


Analysis of the characteristics of industrial energy consumption and carbon emissions. The unit GDP energy consumption intensity refers that at a certain period of time, how much energy a country or region consume by each unit of gross domestic product (GDP). It is a comprehensive index to measure the energy efficiency of a country's economic and social activities, its value reflects the degree of a country's economic development depende on energy, and the economic benefits of energy utilization.The lower the energy consumption intensity shows that the higher the quality of the GDP. Reduce energy intensity is the fundamental means to improve the industrial structure and energy efficiency.

The development of industry is bound to lead to the increase of energy consumption, and with the improvement of resource utilization efficiency, intensity of energy consumption per unit of GDP will decline. Fig. 3 shows the industrial energy consumption and energy intensity change of Beijing-Tianjin-Hebe from2005 to 2012.

As we can see from the Fig. 3 , from 2005 to 2012 the industrial energy consumption growth is a straight line, which from 209.63 million tons of standard coal each year grew to 318.98 million tons of standard coal, and the total energy consumption rose by $52 \%$ in eight years. And the intensity of energy consumption per unit GDP is higher, and the energy consumption is 1.00 tons of standard coal per ten thousand yuan GDP before 2005. And it has been dropped to 0.56 tons of standard coal by 2012.Unit GDP energy consumption decreases with time trend, reflects the consciousness of energy conservation and progress of energy saving technology.

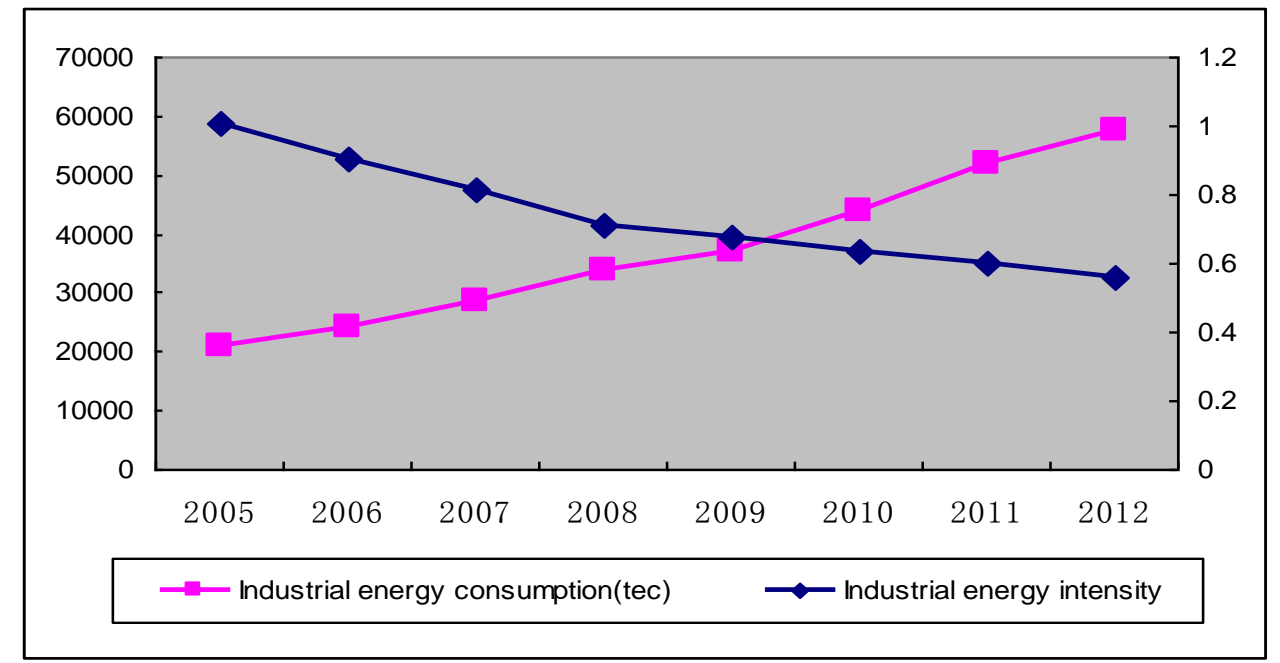

\section{Grey correlation analysis of carbon emissions and industrial structure}

Grey correlation analysis method. Grey correlation analysis method is a multifactor statistical analysis method, and the basic idea is according to the similar degree of sequence curve geometry to judge the correlation degree between the system characteristics and related factors of sequences curve, and the closer the system characteristics and related factors of sequences, the greater the degree of association between them. 
Data source and measurement results. The influence of industrial structure on energy consumption specific has two aspects: scale effect and technical effect.

Scale effect is calculated using industry production value from 2005 to 2012 and the carbon intensity measured by above method. Using grey correlation analysis method, the correlation of beijing-tianjin-hebei industry output value of industry and carbon intensity is as follows.

Table 3 Correlation between beijing-tianjin-hebei industry output value and carbon intensity tables

\begin{tabular}{|c|c|c|c|c|c|}
\hline Industry & $\begin{array}{l}\mathrm{C} \\
\text { orre } \\
\text { lati } \\
\text { on }\end{array}$ & Industry & $\begin{array}{l}\mathrm{C} \\
\text { orre } \\
\text { lati } \\
\text { on }\end{array}$ & Industry & $\begin{array}{l}\mathrm{C} \\
\text { orre } \\
\text { lati } \\
\text { on }\end{array}$ \\
\hline $\begin{array}{l}\text { Six big energy } \\
\text { intensive industries }\end{array}$ & $\begin{array}{l}\quad 0 \\
.77 \\
5\end{array}$ & $\begin{array}{c}\text { Five machinery and } \\
\text { equipment manufacturing }\end{array}$ & $\begin{array}{l}0 \\
.82 \\
8\end{array}$ & $\begin{array}{c}\text { Other } \\
\text { industries }\end{array}$ & $\begin{array}{l}0 \\
.79 \\
7\end{array}$ \\
\hline $\begin{array}{l}\text { Coal mining and } \\
\text { washing industry }\end{array}$ & $\begin{array}{l}\quad 0 \\
.75 \\
2 \\
\end{array}$ & $\begin{array}{l}\text { General equipment } \\
\text { manufacturing industry }\end{array}$ & $\begin{array}{l}\quad 0 \\
.78 \\
0 \\
\end{array}$ & $\begin{array}{l}\text { Oil and gas } \\
\text { industry }\end{array}$ & $\begin{array}{l}0 \\
.75 \\
1 \\
\end{array}$ \\
\hline $\begin{array}{l}\text { Oil processing and } \\
\text { coking and nuclear fuel } \\
\text { processing industry }\end{array}$ & $\begin{array}{l}0 \\
.81 \\
3 \\
\end{array}$ & $\begin{array}{c}\text { Special equipment } \\
\text { manufacturing }\end{array}$ & $\begin{array}{l}\quad 0 \\
.78 \\
1 \\
\end{array}$ & $\begin{array}{l}\text { Ferrous metal } \\
\text { mining }\end{array}$ & $\begin{array}{l}\quad 0 \\
.74 \\
9 \\
\end{array}$ \\
\hline $\begin{array}{l}\text { Chemical raw } \\
\text { materials and chemical } \\
\text { products manufacturing }\end{array}$ & $\begin{array}{l}0 \\
.81 \\
4\end{array}$ & $\begin{array}{l}\text { Transportation } \\
\text { equipment manufacturing } \\
\text { industry }\end{array}$ & $\begin{array}{l}\quad 0 \\
.79 \\
9 \\
\end{array}$ & $\begin{array}{l}\text { Agricultural } \\
\text { food processing } \\
\text { industry }\end{array}$ & $\begin{array}{l}\quad 0 \\
.78 \\
7\end{array}$ \\
\hline $\begin{array}{l}\text { Non-metallic mineral } \\
\text { products }\end{array}$ & $\begin{array}{l}0 \\
.80 \\
9\end{array}$ & $\begin{array}{l}\quad \text { Electrical machinery } \\
\text { equipment manufacturing } \\
\text { industry }\end{array}$ & $\begin{array}{l}0 \\
.81 \\
3\end{array}$ & $\begin{array}{l}\text { Food } \\
\text { manufacturing }\end{array}$ & $\begin{array}{l}0 \\
.77 \\
5\end{array}$ \\
\hline $\begin{array}{l}\text { Black metal smelting } \\
\text { and rolling processing } \\
\text { industry }\end{array}$ & $\begin{array}{l}0 \\
.81 \\
4\end{array}$ & $\begin{array}{l}\text { Communication } \\
\text { equipment, computers and } \\
\text { other electronic equipment } \\
\text { manufacturing industry }\end{array}$ & $\begin{array}{l}0 \\
.87 \\
2\end{array}$ & $\begin{array}{c}\text { Beverage } \\
\text { manufacturing }\end{array}$ & $\begin{array}{l}0 \\
.82^{0} \\
8\end{array}$ \\
\hline \begin{tabular}{l}
\multicolumn{2}{c}{ Electricity, heat } \\
production and supply \\
industry
\end{tabular} & $\begin{array}{l}0 \\
.80 \\
8\end{array}$ & & & & \\
\hline
\end{tabular}

As we can see from the calculation results, the industrial output value has important influence on carbon intensity, its correlation coefficient with carbon intensity is more than 0.6. In addition, the impact of industrial production value of different industries for carbon emissions show certain differences. The correlation coefficient of six major energy-consuming industry output value and the number is 0.775 . The correlation coefficient of five mechanical equipment manufacturing output and carbon intensity is 0.828 . The correlation coefficient of other industry output value and carbon intensity is 0.797 . From the perspective of the differences of the industry, the industry whose output value is highly related to the intensity of carbon emissions (correlation coefficients $>0.85$ ) is communication equipment, computers and other electronic equipment manufacturing. The industry related to carbon emissions in general correlation coefficient $(<0.7)$ includ the cultural and educational sporting goods manufacturing and resource waste and the processing of waste material recycling. 
Technical effect is calculated using industry production value from 2005 to 2012 and the carbon intensity measured by above method. Using grey correlation analysis method, the correlation of beijing-tianjin-hebei industrial energy intensity and carbon intensity correlation is as follows.

Table 4 beijing-tianjin-hebei region industrial sectors between the energy intensity and carbon intensity correlation tables

\begin{tabular}{|c|c|c|c|c|c|}
\hline Industry & $\begin{array}{l}\mathrm{C} \\
\text { orre } \\
\text { lati } \\
\text { on }\end{array}$ & Industry & $\begin{array}{l}\mathrm{C} \\
\text { orre } \\
\text { lati } \\
\text { on }\end{array}$ & Industry & $\begin{array}{l}\mathrm{C} \\
\text { orre } \\
\text { lati } \\
\text { on }\end{array}$ \\
\hline $\begin{array}{l}\text { Six big energy } \\
\text { intensive industries }\end{array}$ & $\begin{array}{l}0 \\
.88 \\
2\end{array}$ & $\begin{array}{l}\text { Five machinery and } \\
\text { equipment manufacturing }\end{array}$ & $\begin{array}{l}0 \\
.85 \\
3\end{array}$ & $\begin{array}{l}\text { Other } \\
\text { industries }\end{array}$ & $\begin{array}{l}0 \\
.86 \\
2\end{array}$ \\
\hline $\begin{array}{l}\text { Coal mining and } \\
\text { washing industry }\end{array}$ & $\begin{array}{l}0 \\
.89 \\
8\end{array}$ & $\begin{array}{l}\text { General equipment } \\
\text { manufacturing industry }\end{array}$ & $\begin{array}{l}\quad 0 \\
.74 \\
7\end{array}$ & $\begin{array}{l}\text { Oil and gas } \\
\text { industry }\end{array}$ & $\begin{array}{l}0 \\
.88^{0} \\
9\end{array}$ \\
\hline $\begin{array}{l}\text { Oil processing and } \\
\text { coking and nuclear fuel } \\
\text { processing industry }\end{array}$ & $\begin{array}{l}0 \\
.91 \\
6 \\
\end{array}$ & $\begin{array}{l}\text { Special equipment } \\
\text { manufacturing }\end{array}$ & $\begin{array}{l}\quad 0 \\
89 \\
7 \\
\end{array}$ & $\begin{array}{l}\text { Ferrous metal } \\
\text { mining }\end{array}$ & $\begin{array}{l}0 \\
.65 \\
1 \\
\end{array}$ \\
\hline $\begin{array}{l}\text { Chemical raw } \\
\text { materials and chemical } \\
\text { products manufacturing }\end{array}$ & $\begin{array}{l}0 \\
.88 \\
8 \\
\end{array}$ & $\begin{array}{l}\text { Transportation } \\
\text { equipment manufacturing } \\
\text { industry }\end{array}$ & $\begin{array}{l}0 \\
.84^{0} \\
4 \\
\end{array}$ & $\begin{array}{l}\text { Agricultural } \\
\text { food processing } \\
\text { industry }\end{array}$ & $\begin{array}{l}0 \\
.88 \\
3 \\
\end{array}$ \\
\hline $\begin{array}{l}\text { Non-metallic mineral } \\
\text { products }\end{array}$ & $\begin{array}{l}\quad 0 \\
.89 \\
0\end{array}$ & $\begin{array}{l}\quad \text { Electrical machinery } \\
\text { equipment manufacturing } \\
\text { industry }\end{array}$ & $\begin{array}{l}0 \\
.84 \\
4 \\
\end{array}$ & $\begin{array}{l}\text { Food } \\
\text { manufacturing }\end{array}$ & $\begin{array}{l}\quad 0 \\
.88 \\
9\end{array}$ \\
\hline $\begin{array}{l}\text { Black metal smelting } \\
\text { and rolling processing } \\
\text { industry }\end{array}$ & $\begin{array}{l}0 \\
.86 \\
7\end{array}$ & $\begin{array}{l}\text { Communication } \\
\text { equipment, computers and } \\
\text { other electronic equipment } \\
\text { manufacturing industry }\end{array}$ & $\begin{array}{l}0 \\
.85 \\
1\end{array}$ & $\begin{array}{c}\text { Beverage } \\
\text { manufacturing }\end{array}$ & $\begin{array}{l}0 \\
.89 \\
7\end{array}$ \\
\hline \begin{tabular}{l}
\multicolumn{1}{c}{ Electricity, heat } \\
production and supply \\
industry
\end{tabular} & $\begin{array}{l}0 \\
.88 \\
6\end{array}$ & & & & \\
\hline
\end{tabular}

As we can see from the calculation results, energy intensity also has important influence on carbon intensity, but the influence of the industrial energy intensity to carbon emissions intensity show certain differences by different industries. The correlation coefficient of six major energy-consuming industry and the carbon intensity is 0.882 . The correlation coefficient of five mechanical equipment manufacturing and carbon intensity 0.853 . The correlation coefficient of other industry and carbon intensity is 0.862 .From the perspective of the differences of the industry, the industry whose energy consumption intensity is highly related to the intensity of carbon emissions (correlation coefficients $>0.9$ ) is oil processing and coking and nuclear fuel processing industry. The industry related to carbon emissions in general correlation coefficient $(<0.7)$ includ ferrous metal mining, non-ferrous metal smelting and rolling processing industry and gas production and supply industry. 


\section{References}

[1] Liu Lina and Zhao Hechun, The influence factors of the low carbon economy development of our country and the policy choice, China's collective economy, vol.1, pp. 27-28, 2012.

[2] Guo Li , Cui Qiang and Lu Min, New tools of low carbon life-The carbon labels, Ecological economy, vol.7, pp. 84-86,94,2011.

[3] Liu Hongguang, Analysis of $\mathrm{Co} 2$ emission reduction effect of China's regional industrial structure adjustment-Based on the analysis of the regional input-output table, Regional research and development, vol.3, pp.129-135,2010.

[4] Chen Shiyi, Energy consumption and $\mathrm{Co} 2$ emissions and the sustainable development of Chinese industry, Economic research, vol.4, pp.41-55,2009.

[5] Chen Wei and Qi Yanbin, Regression analysis of low carbon agricultural development factors, The rural economy, vol.2, pp.19-23, 2010

[6] Du Dong, Pang Qinghua and Wu Yan, Modern comprehensive evaluation method and case selection, Tsinghua university press (social science, economic class), pp.111-138,2008.

[7] Zhang Yan and Chen Wei, Low carbon economy and the regional industrial structure adjustment, Intellectual property rights press,2014.

[8] Chen Shiyi, Energy consumption and $\mathrm{Co} 2$ emissions and the sustainable development of Chinese industry, Economic research, vol.4, pp.41-55,2009.

[9] Andrea Baranzini , Jose Goldemberg, Stefan Speck. A future for carbon taxes[J].Ecological Economics, 2009,32(2000):395-412.

[10] Alla ,R.The British Industrial Revolution in Global Perspective [M].Cambridge University Press, Cambridge,2009. 